\title{
The consequences of saline irrigation treatments on soil physicochemical characteristics
}

\author{
Zied Haj-Amor $^{1} \cdot$ Hossein Hashemi ${ }^{2} \cdot$ Salem Bouri ${ }^{1}$
}

Received: 6 December 2017 / Accepted: 17 April 2018 / Published online: 29 May 2018

(c) The Author(s) 2018

\begin{abstract}
When saline water is used to irrigate crops in arid environments, appropriate irrigation management should be applied to avoid negatively impacting soil characteristics. In this study, the effects of irrigating date palms with saline water $\left(2.24 \mathrm{~g}^{-1}\right)$ on soil physicochemical characteristics such as the electrical conductivity $\left(\mathrm{EC}_{\mathrm{e}}\right)$, the $\mathrm{pH}$ of the saturated soil paste $\left(\mathrm{pH}_{\mathrm{e}}\right)$, the concentrations of soluble cations $\left(\mathrm{Ca}^{2+}, \mathrm{Mg}^{2+}, \mathrm{Na}^{+}\right)$, the sodium adsorption ratio (SAR), the saturated soil hydraulic conductivity $\left(K_{\mathrm{s}}\right)$, and the volumetric water content of the soil $\left(\theta_{\mathrm{v}}\right)$ were evaluated in a Tunisian Saharan cropland, the Dergine Oasis, during a 4-year period (2012-2015). The effects of three different irrigation treatments of date palms on soil properties were investigated: low treatment ( $90 \%$ of the net irrigation requirement (NIR) of date palms was applied); medium treatment (100\% of NIR was applied), and high treatment (110\% of NIR was applied). The results showed that the application of saline water for irrigation inevitably has a negative impact on the physicochemical properties of the soil. Irrigation with saline water was observed to have severe negative impacts on the soil characteristics, especially $\mathrm{EC}_{\mathrm{e}}, \mathrm{Na}^{+}, K_{\mathrm{s}}$, and $\theta_{\mathrm{v}}$. However, among the three irrigation treatments applied, statistical analysis (Duncan's multiple range test) indicated that the high treatment significantly $(p<0.05)$ minimized the degradation of soil characteristics by the saline water; this treatment decreased $\mathrm{EC}_{\mathrm{e}}, \mathrm{Na}^{+}$, and SAR and increased the water content, $\theta_{\mathrm{v}}$, of the studied soil.
\end{abstract}

Keywords Irrigation treatment $\cdot$ Soil characteristics $\cdot$ Saline water $\cdot$ Arid environments $\cdot$ Oasis

\section{Introduction}

In arid regions, meager rainfall (annual amounts vary between 100 and $300 \mathrm{~mm}$; FAO 1989) coupled with an extreme shortage of fresh groundwater necessitate the use of saline groundwater to satisfy the water demands of the agricultural sector (Kolsi et al. 2013; Zaidi and Kassem 2012). This saline groundwater arises through processes known as primary and secondary salinization. Primary salinization occurs naturally in groundwater where there is naturally occurring salt (e.g., halite and gypsum) in the parent aquifer material or lateral flow from adjacent saline aquifers. Secondary salinization arises through human activities,

Zied Haj-Amor

ziedhadj@yahoo.com

1 Water, Energy, and Environment Laboratory, National Engineering School of Sfax, 3038 Sfax, Tunisia

2 Department of Water Resources Engineering, and Center for Middle Eastern Studies, Lund University, Box 118, 22100 Lund, Sweden primarily land-use changes, development, and agricultural activities such as increased crop production resulting from the intensive use of agrochemicals (Knapp and Baerenklau 2006). During the past few decades, a rapid increase in irrigated lands and the climatic conditions of the Saharan environment have together caused major salinization of the groundwater resources in this region; consequently, intensive exploitation of saline groundwater has led to severe degradation of agricultural soil (King and Thomas David 2014). Indeed, soil salinization is considered the main reason for cropland degradation in these areas. Hamdy (2005) reported that the soil salinization process has negatively affected about $30 \%$ of the irrigated lands in the Sahara.

As demonstrated by numerous researchers (e.g., Amézketa 1999; Tedeschi and Dell'Aquila 2005; Al-Zu'bi Y 2007; Huang et al. 2011; Askri et al. 2014), frequent irrigation with saline water can accelerate the soil salinization process, significantly degrading the quality of agricultural soil in various ways. A high concentration of salt, especially sodium salt, in the soil can cause physicochemical deterioration of the soil. This can lead to structural damage to the 
soil due to the dispersion of clay particles, decreased soil hydraulic conductivity, soil instability due to the clogging of soil pores, and the formation of a thin crust at the surface of the soil, which reduces the rate of infiltration of irrigation water into the soil profile. Physicochemical deterioration of the soil also leads to a severe reduction in soil productivity, hence degrading soil fertility (Al-Zu'bi 2007).

The appropriate management of saline water and the soil to ensure sustainable agriculture in Saharan croplands by avoiding or minimizing the adverse effects of saline water on agricultural soil is therefore an extremely important issue. Key to achieving sustainable agricultural management is a good understanding of the processes behind the degradation of soil physicochemical characteristics by the saline irrigation water (Tedeschi et al. 2007). Particular attention needs to be paid to agricultural soils that receive large amounts of water through surface irrigation, considering the complexity involved in maintaining a safe level of salinity within the soil (Huang et al. 2011). In the Saharan croplands, the considerable water requirements of date palms Phoenix dactylifera (Sperling et al. 2014) lead to the application of enormous volumes of saline water during the irrigation process (Tripler et al. 2011). A number of studies have addressed the effect of saline irrigation water on soil physicochemical characteristics (e.g., Al-Zu'bi 2007; Huang et al. 2011; Singh et al. 2011), but very few studies have studied this effect for soil in which date palms are growing. The primary objectives of the work reported in the present paper were therefore to assess the effects of four years of irrigation of date palms with saline water on the characteristics of the soil, and to identify the appropriate irrigation treatment (i.e., the appropriate volume of saline water) that will minimize the degradation of soil physicochemical characteristics.

\section{Materials and methods}

\section{The Dergine Oasis}

Field work was performed during a 4-year period between January 2012 and December 2015 in the Dergine Oasis (Fig. 1), a modern Saharan irrigated oasis located in southwestern Tunisia, where environmental conditions (De Grenade 2013) favor the growth of date palms. The climate of the study area is arid (the average yearly rainfall rarely exceeds $90 \mathrm{~mm}$ ) and hot (exceeding $40{ }^{\circ} \mathrm{C}$ in the summer months). In contrast, the average annual potential evapotranspiration reaches $1800 \mathrm{~mm}$. The average monthly relative humidity varies between 62 and 32\% in December and August, respectively (El-Fahem 2003). In 2003, the Dergine Oasis, 88 ha in area, was completely planted with the date palm Phoenix dactylifera to a density of 120 palms per hectare. These trees receive surface irrigation with saline water $\left(3.5 \mathrm{dS} \mathrm{m}^{-1} \approx 2.24 \mathrm{~g} \mathrm{l}^{-1}\right)$ supplied by a deep artesian well with a depth of $175 \mathrm{~m}$. Chemical and physical properties of the applied irrigation water are given in Table 1 . The soil texture is loamy sand and gypsum is present throughout the oasis (depth concentration: $1 \mathrm{~m}$; average gypsum distribution: $6 \%$ ). The extensive application of saline water to irrigate the palm trees as well as the unsuitable agricultural soil (loamy-sand soil with a high infiltration rate) have led to the creation of a shallow saline groundwater layer at an average depth of less than $2 \mathrm{~m}$ in the studied oasis (Askri and Bouhlila 2010). To prevent the potential for this shallow groundwater layer to cause irrigated soil salinization, the oasis was protected with a subsurface drainage system (buried pipe drains) installed at a depth of $1.5 \mathrm{~m}$. The drainage system is designed to stop the water table from rising to a critical
Fig. 1 Location of the Dergine Oasis in the town of Douz, Kebili, southwestern Tunisia

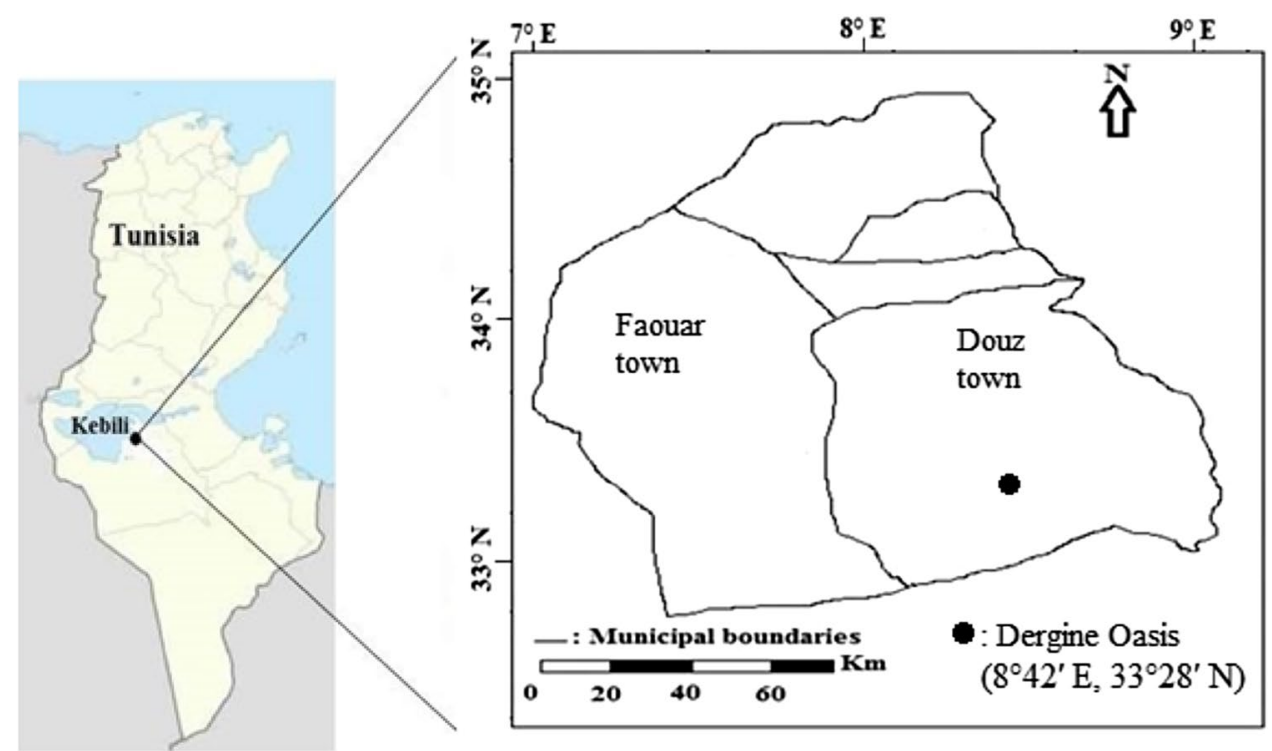


Table 1 Chemical and physical properties of the saline irrigation water applied in the Dergine Oasis (data based on the analysis of 12 samples taken in the year 2012, i.e., one sample per month)

\begin{tabular}{|c|c|c|c|}
\hline Parameter & Minimum & Maximum & Average \\
\hline $\mathrm{EC}_{\mathrm{iw}}\left(\mathrm{dS} \mathrm{m}^{-1}\right)$ & 3.40 & 3.62 & 3.51 \\
\hline SAR & 4.70 & 6.10 & 5.80 \\
\hline $\mathrm{pH}_{\mathrm{e}}(-)$ & 7.83 & 7.92 & 7.87 \\
\hline $\mathrm{Na}^{+}\left(\right.$meq L $\left.{ }^{-1}\right)$ & 12.50 & 18.50 & 16.6 \\
\hline $\mathrm{Ca}^{2+}\left(\right.$ meq L $\left.{ }^{-1}\right)$ & 7.20 & 09.36 & 8.40 \\
\hline $\mathrm{Mg}^{2+}\left(\right.$ meq L $\left.{ }^{-1}\right)$ & 6.62 & 8.75 & 7.80 \\
\hline $\mathrm{K}^{+}\left(\right.$meq $\left.\mathrm{L}^{-1}\right)$ & 0.25 & 0.32 & 0.30 \\
\hline $\mathrm{Cl}^{-}\left(\right.$meq L L $\left.\mathrm{L}^{-1}\right)$ & 12.17 & 14.20 & 13.3 \\
\hline $\mathrm{SO}_{4}^{2-}\left(\mathrm{meq} \mathrm{L} \mathrm{L}^{-1}\right)$ & 10.12 & 11.19 & 10.8 \\
\hline $\mathrm{HCO}_{3}^{-}\left(\right.$meq L L $\left.{ }^{-1}\right)$ & 2.10 & 3.30 & 2.80 \\
\hline $\mathrm{Na}(\%)$ & 24.0 & 28.0 & 27.0 \\
\hline
\end{tabular}

soil depth of $1.5 \mathrm{~m}$ (defined based on the agroclimatic and soil conditions in the oasis; Ben Aissa et al. 2013; Bouarfa et al. 2009).

\section{Experimental design and monitored plots}

The main objective of the present work was to investigate the effect of saline water quantity (irrigation treatment) on soil physicochemical characteristics. To achieve this aim, the soil characteristics observed following the application of different quantities of saline water were investigated. Three irrigation treatments (Table 2) were applied in three different plots (Fig. 2) located in the Dergine Oasis during the studied period (2012-2015). These plots were selected largely on the basis of their location within the Dergine Oasis (Fig. 2). The

Table 2 Properties of the monitored plots and the irrigation treatments applied to them

\begin{tabular}{llllllll}
\hline Plot & $\begin{array}{l}\text { Surface area } \\
\text { (ha) }\end{array}$ & Soil texture $^{\mathrm{a}}$ & $\begin{array}{l}\text { Irrigation } \\
\text { frequency } \\
\text { (days) }\end{array}$ & $\begin{array}{l}\text { Number of irriga- } \\
\text { tion events }^{\mathrm{b}}\end{array}$ & $\begin{array}{l}\text { Palm density } \\
\left(\text { palms ha }{ }^{-1}\right)\end{array}$ & Water quantity & Irrigation treatment type \\
\hline Plot 1 & 0.5 & Loamy-sand & 15 & 96 & 120 & $90 \%$ of NIR & Low treatment \\
Plot 2 & 0.5 & Loamy-sand & 15 & 96 & 120 & $100 \%$ of NIR & Medium treatment \\
Plot 3 & 0.5 & Loamy-sand & 15 & 96 & 120 & $110 \%$ of NIR & High treatment \\
\hline
\end{tabular}

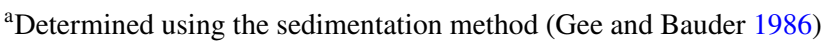

${ }^{\mathrm{b}}$ Applied during the studied period (2012-2015)

${ }^{\mathrm{c}} \mathrm{NIR}$ is the net irrigation requirement of date palms (NIR = actual evapotranspiration $\left(\mathrm{ET}_{\mathrm{a}}\right)+$ leaching requirement $\left.(\mathrm{LR})\right)$

Fig. 2 Irrigation system topology in the Dergine Oasis and locations of the three monitored plots (plots 1,2, and 3)

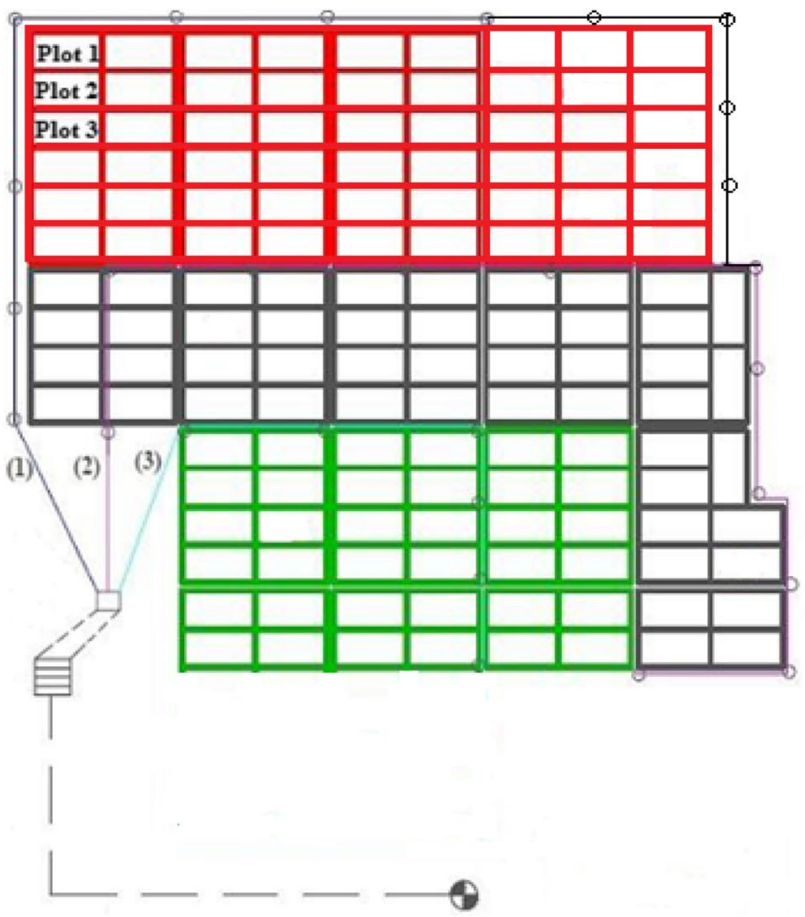

Scale:

$\underline{0} \quad 100 \quad 200-\mathrm{m}$

Legend:

: Artesian well

Plot 1, 2 and 3 : Control plots 
selected plots (the three in the top left corner in the figure) were the most elevated plots, so they did not receive lateral shallow groundwater flow from neighboring irrigated plots. In other words, we eliminated the possibility that lateral flow from neighboring plots could influence the properties of the soil in each plot of interest. No significant rainfall was recorded during the study period, meaning that the soil in the studied plots mainly received moisture from irrigation. Whereas palm trees were planted in the other plots in the Dergine Oasis in 2003, the palms in the monitored plots were planted in January 2012 (at the beginning of the studied period) and were surface irrigated using available saline water (Table 1). The quantity of saline water applied to each plot over the studied period is presented in Table 3 . It should be mentioned that regular and adequate drainage was observed in all monitored plots.

\section{Soil sampling}

The soil properties of all monitored plots (plots 1-3) were investigated by analyzing the first $90 \mathrm{~cm}$ of the soil profile in each plot $(90 \mathrm{~cm}$ is the maximum depth of the root zone for planted date palms). In the soil profile, three soil horizons were identified: $0-30,30-60$, and $60-90 \mathrm{~cm}$. The variations in the properties of the soil within those horizons were determined. Throughout the studied period (2012-2015), 96 irrigation events were recorded for each plot (Table 2). Soil samples were collected from each plot at the three depth intervals $24 \mathrm{~h}$ after each irrigation event. A truck-mounted hydraulic push probe (Giddings Machine Company, Fort Collins, CO, USA) was used to collect intact soil samples. This allowed 288 soil samples to be collected from each plot (96 irrigation events $\times 3$ soil layers), or 864 samples in total (96 irrigation events $\times 3$ soil layers $\times 3$ plots). The collected soil samples were subject to careful physical and chemical analyses carried out via standard methods (Page et al. 1982). Before the analyses, all of the collected soil samples were dried for $24 \mathrm{~h}$, crushed, and sieved using a screen with a grid size of $2 \mathrm{~mm}$ and then stored for further analyses.

Chemical analyses of the collected soil samples included the $\mathrm{pH}$ of the saturated soil paste $\left(\mathrm{pH}_{\mathrm{e}}\right)$, the electrical conductivity $\left(\mathrm{EC}_{\mathrm{e}}\right)$, soluble cation concentrations $\left(\mathrm{Ca}^{2+}, \mathrm{Mg}^{2+}\right.$,

Table 3 Total amount of water applied (in $\mathrm{mm}$ ) to each of the monitored plots during the studied period (2012-2015)

\begin{tabular}{llll}
\hline Years & $\begin{array}{l}\text { Plot 1 } \\
\text { (low treatment) }\end{array}$ & $\begin{array}{l}\text { Plot 2 } \\
\text { (medium treat- } \\
\text { ment) }\end{array}$ & $\begin{array}{l}\text { Plot 3 } \\
\text { (high treatment) }\end{array}$ \\
\hline 2012 & 1245 & 1386 & 1464 \\
2013 & 1278 & 1398 & 1481 \\
2014 & 1288 & 1409 & 1492 \\
2015 & 1293 & 1422 & 1518 \\
\hline
\end{tabular}

$\mathrm{Na}^{+}$), and the sodium adsorption ratio (SAR). The cation concentrations and the SAR were measured for a saturated extract, whereas $\mathrm{pH}_{\mathrm{e}}$ and $\mathrm{EC}_{\mathrm{e}}$ were measured in a 1:5-diluted extract ("1 soil//5 water"). Physical analyses of the collected soil samples included the saturated soil hydraulic conductivity $(K)$ and the volumetric water content of the soil $\left(\theta_{\mathrm{v}}\right)$. Each soil property was measured in four replicates to check the consistency of the results. Furthermore, for each plot, the effect of the local heterogeneity on the soil physicochemical property measurements was neglected due to the size of the investigated plot $(0.5 \mathrm{ha})$ as well as the homogeneity of the texture of the soil (loamy sand).

\section{Electrical conductivity of the saturated soil paste $\left(E C_{e}\right)$}

This parameter was measured to evaluate the level of soil salinization. A high soil salinization level, especially around the roots of the crop, imposes ion toxicity, osmotic stress, nutrient deficiency, and oxidative stress on crops and limits their uptake of water from the soil, decreasing crop production (Shrivastava and Kumar 2015). High soil salinity can also negatively affect many soil physicochemical characteristics such as soil structure and soil porosity (Huang et al. 2011).

Following the method proposed by Rhoades (1996), a filtrate was first extracted from a 1 soil $/ 5$ water mixture to measure the electrical conductivity of the 1:5-diluted extract $\left(\mathrm{EC}_{1 / 5}\right)$. The extraction process was performed through a Buchner funnel. A linear regression equation was then derived for each soil layer (Eqs. 2.1, 2.2, and 2.3 below) to convert the $\mathrm{EC}_{1 / 5}$ values into electrical conductivity values of the saturated soil paste $\left(\mathrm{EC}_{\mathrm{e}}\right)$. The 864 soil samples collected from the Dergine Oasis (96 samples from each soil layer) were used to establish the relationships between $\mathrm{EC}_{1 / 5}$ and $\mathrm{EC}_{\mathrm{e}}$ (regression coefficients $R^{2}>0.95$ ). The measured $\mathrm{EC}_{\mathrm{e}}$ was expressed in $\mathrm{dS} \mathrm{m}^{-1}$.

$$
\begin{aligned}
& \mathrm{EC}_{\mathrm{e}}=1.89+1.11 \times \mathrm{EC}_{1 / 5}\left(0-30 \mathrm{~cm} ; R^{2}=0.98\right) \\
& \mathrm{EC}_{\mathrm{e}}=1.63+1.16 \times \mathrm{EC}_{1 / 5}\left(30-60 \mathrm{~cm} ; R^{2}=0.97\right)
\end{aligned}
$$

$\mathrm{EC}_{\mathrm{e}}=1.59+1.27 \times \mathrm{EC}_{1 / 5}\left(60-90 \mathrm{~cm} ; R^{2}=0.95\right)$

\section{$\mathrm{pH}$ of the saturated soil paste $\left(\mathrm{pH}_{\mathrm{e}}\right)$}

This parameter is considered a key influence on the physicochemical condition of the soil and on plant growth (Roy et al. 2006). The filtrate used for $\mathrm{EC}_{1 / 5}$ measurements was also employed to conduct $\mathrm{pH}$ measurements with a glasselectrode $\mathrm{pH}$ meter. The obtained values $\left(\mathrm{pH}_{1 / 5}\right)$ were transformed into the $\mathrm{pH}$ of the saturated soil paste $\left(\mathrm{pH}_{\mathrm{e}}\right)$ based on 
established relationships between $\mathrm{pH}_{1 / 5}$ and $\mathrm{pH}_{\mathrm{e}}$ for the three soil layers (Eqs. 2.4, 2.5, and 2.6 below). The soil samples collected for each layer (80 samples) in the Dergine Oasis were used to establish the relationship between $\mathrm{pH}_{1 / 5}$ and $\mathrm{pH}_{\mathrm{e}}$ for each layer.

$$
\begin{aligned}
& \mathrm{pH}_{\mathrm{e}}=0.21+1.02 \times \mathrm{pH}_{1 / 5}\left(0-30 \mathrm{~cm} ; R^{2}=0.96\right) \\
& \mathrm{pH}_{\mathrm{e}}=0.18+1.13 \times \mathrm{pH}_{1 / 5}\left(30-60 \mathrm{~cm} ; R^{2}=0.94\right) \\
& \mathrm{pH}_{\mathrm{e}}=0.11+1.22 \times \mathrm{pH}_{1 / 5}\left(60-90 \mathrm{~cm} ; R^{2}=0.97\right)
\end{aligned}
$$

\section{Soluble cation concentrations $\left(\mathrm{Ca}^{2+}, \mathrm{Mg}^{2+}\right.$, and $\left.\mathrm{Na}^{+}\right)$}

The sodium cation $\left(\mathrm{Na}^{+}\right)$concentration was measured using a flame photometer (model 410, Corning Inc., Corning, NY, USA). The calcium $\left(\mathrm{Ca}^{2+}\right)$ and magnesium $\left(\mathrm{Mg}^{2+}\right)$ cation concentrations were measured with an atomic absorption spectrophotometer (model SP3, Pye Unicam, Cambridge, UK). The guideline proposed by Page et al. (1982) was followed when measuring the $\mathrm{Ca}^{2+}, \mathrm{Mg}^{2+}$, and $\mathrm{Na}^{+}$ concentrations.

\section{Sodium adsorption ratio (SAR)}

This parameter was analyzed to probe the potential for soil properties, especially the soil structure, to be degraded by high sodium concentrations (with respect to the calcium and magnesium concentrations) in the irrigation water. The measured $\mathrm{Ca}^{2+}, \mathrm{Mg}^{2+}$, and $\mathrm{Na}^{+}$concentrations were used to calculate the sodium adsorption ratio (SAR) using Eq. 2.7 below (Oster and Sposito 1980):

$\mathrm{SAR}=\frac{\left(\mathrm{Na}^{+}\right)}{\sqrt{\frac{1}{2}\left(\mathrm{Ca}^{2+}+\mathrm{Mg}^{2+}\right)}}$,

where ionic concentrations are expressed in meq $\mathrm{L}^{-1}$.

\section{Soil hydraulic conductivity $\left(K_{s}\right)$}

The saturated hydraulic conductivity $\left(K_{\mathrm{s}}\right)$ of each soil core sample was determined based on the constant-head method described by Blake and Hartge (1986). For this purpose, the collected intact soil cores $(8.2 \mathrm{~cm}$ in length and $6.2 \mathrm{~cm}$ in diameter) from the studied plots and soil layers were saturated in the laboratory. The saturated hydraulic conductivity $\left(K_{\mathrm{s}}\right)$ values of the samples were then measured using a constant-head permeameter. We strictly followed the guideline for $K_{\mathrm{s}}$ measurements produced by Gholizadeh-Sarabi and Sepaskhah (2013) regarding the laboratory materials required, the measurement steps to perform, and the calculation method to use. $K_{\mathrm{s}}$ was calculated using the following equation and expressed in $\mathrm{cm} \mathrm{day}^{-1}$ :

$K_{\mathrm{s}}=\frac{\Delta \mathrm{V}}{\Delta T \times i \times A}$,

where $\Delta V$ is the volume of the inflow or outflow, $\Delta T$ is the time step, $i$ is the hydraulic gradient, and $A$ is the crosssectional area of the soil column (for more details, see Gholizadeh-Sarabi and Sepaskhah 2013).

\section{Volumetric water content $\left(\theta_{v}\right)$}

In each of the three monitored plots, the volumetric soil water content $\left(\theta_{\mathrm{v}}\right)$ in each soil layer $(0-30,30-60$, and $60-90 \mathrm{~cm}$ ) was measured $24 \mathrm{~h}$ after each irrigation event (to ensure that the soil conditions had stabilized after irrigation). The $\theta_{\mathrm{v}}$ measurements were performed in situ using a timedomain reflectometry (TDR) probe (TRASE 6050X1, Soil Moisture Corporation Company, Goleta, CA, USA). The TDR probe was calibrated according to the method reported in Hamouda et al. (2005). As recommended by Cichota et al. (2008), the direct measurement of $\theta_{v}$ by TDR is an appropriate technique for soil with a high potential salt concentration. The values of $\theta_{\mathrm{v}}$ were expressed in $\mathrm{cm}^{3} \mathrm{~cm}^{-3}$.

\section{Statistical analysis}

The data collected, i.e., the measurements of soil properties in the three monitored plots obtained during 2012-2015, were analyzed using a standard statistical approach. Differences between the soil property values obtained under the three irrigation treatments (low, medium, and high; Table 2) were detected using analysis of variance (ANOVA). Duncan's multiple range (DMR) test at a significance level of 0.05 (Duncan 1955) was conducted to identify which of the values differed significantly among the three irrigation treatments. The SPSS software package (Kinnear and Gray 2000) was used to perform this statistical analysis. The DMR test is very useful for distinguishing the impacts of various treatments on soil properties and for identifying the best amount of saline irrigation water to apply to minimize the degradation of soil physicochemical characteristics.

\section{Results and discussion}

During the studied period, the shallow groundwater did not rise to the critical soil depth $(2 \mathrm{~m})$ after each irrigation event. For this reason, we ignored any contribution of the groundwater to the deterioration in soil properties. Therefore, the main focus of the present study was to assess the impact of the saline irrigation water on the soil characteristics. 
In the following section, we present the soil properties recorded for plot 2 before irrigation (i.e., just before the first irrigation event in the first year) and after irrigation (i.e., just after the last irrigation event in the fourth year). This is because a normal irrigation treatment (i.e., $100 \%$ of the net irrigation requirements of date palms) was applied to plot 2 during the studied period. We also compare the impacts of the different treatments in the three monitored plots on the soil physicochemical properties.

\section{Effect of saline irrigation water on soil characteristics}

We now present a comparison of the soil physicochemical characteristics before (January 2012) and after (December $2015)$ the application of saline water for irrigation to plot 2 (a medium irrigation treatment was applied in this plot). It is apparent from the results presented in Table 4 that the application of saline water for irrigation $\left(2.24 \mathrm{~g} \mathrm{l}^{-1}\right.$ salinity) significantly $(p<0.05)$ changed the soil physicochemical characteristics in all three soil layers. As presented in Table 4, $\mathrm{pH}_{\mathrm{e}}$ decreased from neutral (7.2-6.9) in January 2012 to slightly acidic (6.5-6.1) by the end of the studied period. As reported by Roy et al. (2006), microbial activity and nutrient efficiency are maximized in neutral to slightly acidic soil, thus facilitating optimal crop growth. Also, the density of palm roots in the deep $(60-90 \mathrm{~cm})$ soil layer increases over time (Zaid and Jiménez 2002), which increases the amount of organic acid in this layer (i.e., the $\mathrm{pH}$ decreased with soil depth). This may be another reason for the increase in the observed soil acidity following three years of the saline water irrigation treatment.

Regarding the effects of the applied saline irrigation water on the soluble cation concentrations $\left(\mathrm{Ca}^{2+}, \mathrm{Mg}^{2+}\right.$, and $\left.\mathrm{Na}^{+}\right)$ in plot 2 , the following findings should be noted. First, the saline irrigation water decreased the calcium $\left(\mathrm{Ca}^{2+}\right)$ concentration in the studied soil. The acidity level of the irrigated soil may be the main reason for this noticeable decrease (Fig. 3). Good irrigation management by the farmers during the studied period (i.e., a strategy to reduce the gypsum

Table 4 Comparison of soil properties before (January 2012) and after (December 2015) irrigation treatment in monitored plot 2

\begin{tabular}{|c|c|c|c|c|c|c|}
\hline \multirow[t]{2}{*}{ Parameter } & \multicolumn{2}{|l|}{ Soil layer: $0-30 \mathrm{~cm}$} & \multicolumn{2}{|c|}{ Soil layer: $30-60 \mathrm{~cm}$} & \multicolumn{2}{|c|}{ Soil layer: $60-90 \mathrm{~cm}$} \\
\hline & Before irrigation & After irrigation & Before irrigation & After irrigation & Before irrigation & After irrigation \\
\hline $\mathrm{EC}_{\mathrm{e}}\left(\mathrm{dS} \mathrm{m} \mathrm{m}^{-1}\right)$ & 6.20 & 8.62 & 5.81 & 9.84 & 4.71 & 11.81 \\
\hline $\mathrm{pH}_{\mathrm{e}}(-)$ & 7.20 & 6.50 & 7.10 & 6.40 & 6.90 & 6.10 \\
\hline $\mathrm{Na}^{+}\left(\right.$meq L $\left.{ }^{-1}\right)$ & 34.50 & 44.50 & 32.50 & 42.60 & 30.50 & 40.30 \\
\hline $\mathrm{Ca}^{2+}\left(\mathrm{meq} \mathrm{L}^{-1}\right)$ & 36.20 & 28.36 & 34.4 & 26.4 & 32.4 & 25.4 \\
\hline $\mathrm{Mg}^{2+}\left(\mathrm{meq} \mathrm{L}{ }^{-1}\right)$ & 17.62 & 13.75 & 14.8 & 12.8 & 13.8 & 11.8 \\
\hline SAR (-) & 6.60 & 9.70 & 6.50 & 9.60 & 6.40 & 9.50 \\
\hline$K_{\mathrm{s}}\left(\mathrm{cm} \mathrm{day}^{-1}\right)$ & 99.32 & 81.25 & 91.22 & 76.31 & 85.31 & 72.13 \\
\hline$\theta_{\mathrm{v}}\left(\mathrm{cm}^{3} \mathrm{~cm}^{-3}\right)$ & 0.064 & 0.032 & 0.082 & 0.041 & 0.098 & 0.044 \\
\hline
\end{tabular}
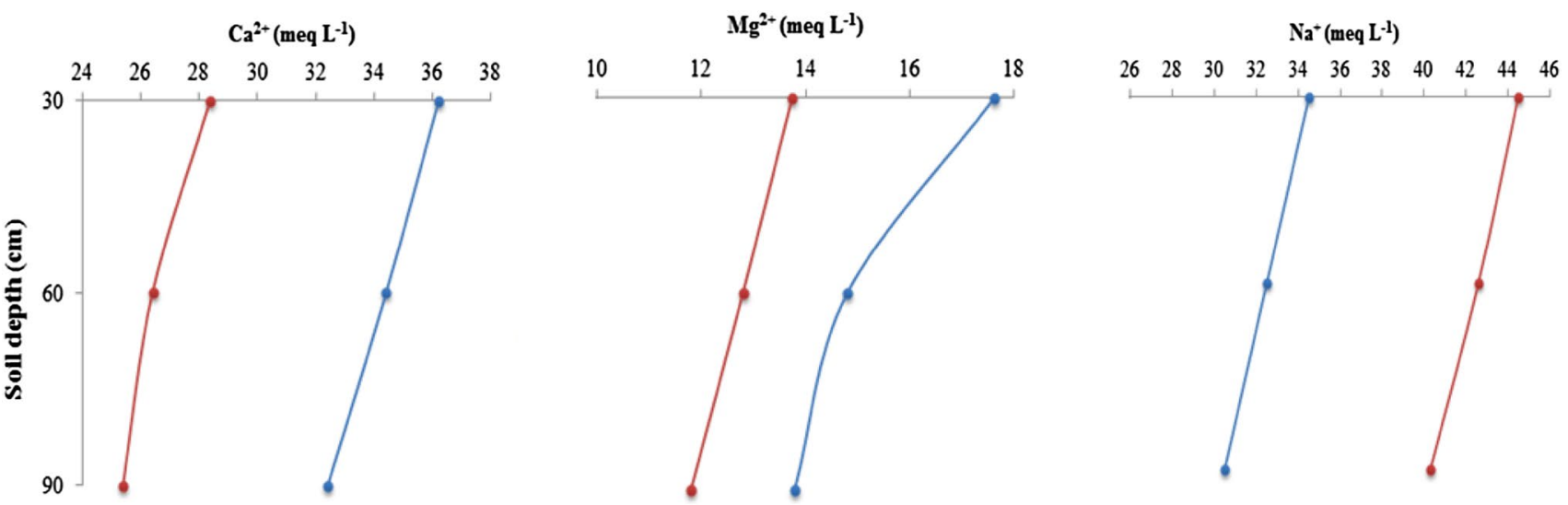

\section{-Before irrigation $\rightarrow$ After irrigation}

Fig. 3 Comparison of the soluble cation $\left(\mathrm{Ca}^{2+}, \mathrm{Mg}^{2+}\right.$, and $\left.\mathrm{Na}^{+}\right)$concentrations observed before and after irrigation 
concentration) could be another reason for this decrease. Second, a significant decrease in the magnesium $\left(\mathrm{Mg}^{2+}\right)$ concentration was also observed at the end of the studied period (Fig. 3). A low $\mathrm{Mg}^{2+}$ concentration in the irrigated soil hinders the growth of planted trees, as $\mathrm{Mg}^{2+}$ deficiency leads to leaf yellowing with brilliant tints (Roy et al. 2006). This was observed in the date palms planted in the Dergine Oasis after applying saline water for irrigation. Third, in contrast to the $\mathrm{Ca}^{2+}$ and $\mathrm{Mg}^{2+}$ concentrations, a significant increase in the $\mathrm{Na}^{+}$concentration was noted after the irrigation period (Fig. 3). This is most likely due to the high $\mathrm{Na}^{+}$ concentration in the applied irrigation water (the $\mathrm{Na}^{+}$level in the irrigation water is presented in Table 1). Generally, the three common cations in the studied soil can be listed as follows in order of how negatively their concentrations were impacted by the saline irrigation water: $\mathrm{Na}^{+}>\mathrm{Ca}^{2+}>\mathrm{Mg}^{2+}$.

The observed decreases in $\mathrm{Ca}^{2+}$ and $\mathrm{Mg}^{2+}$ concentrations and the increase in $\mathrm{Na}^{+}$concentration were employed to calculate the sodium adsorption ratio (SAR) using Eq. 2.7. The result showed that there was a major increase in the SAR over the studied period (Fig. 4). Al-Rasbi (2010) suggest that a continuous increase in the SAR in irrigated soil could degrade date palm growth characteristics such as plant height, plant girth, and leaf length. Hence, it is very important to reduce the SAR level in the irrigated soil.

After four years of irrigation with saline water, a significant increase in the electrical conductivity $\left(\mathrm{EC}_{\mathrm{e}}\right)$ of the irrigated soil was observed (Fig. 5). This implied a progressive accumulation of salt in the soil profile during the studied period. As seen in Fig. 5, the $\mathrm{EC}_{\mathrm{e}}$ of the irrigated soil exceeded the desired $\mathrm{EC}_{\mathrm{e}}$ level of the date palm $\left(<4 \mathrm{dS} \mathrm{m}^{-1}\right.$; Maas and Hoffman 1977). A similar salinization trend has been noted for irrigated soil in many other Tunisian Saharan oases (e.g., Askri and Bouhlila 2010; Haj-Amor et al. 2016). It appears that the climatic conditions of Tunisian Saharan oases (rainfall $<80 \mathrm{~mm} \mathrm{year}^{-1}$ and evapotranspiration

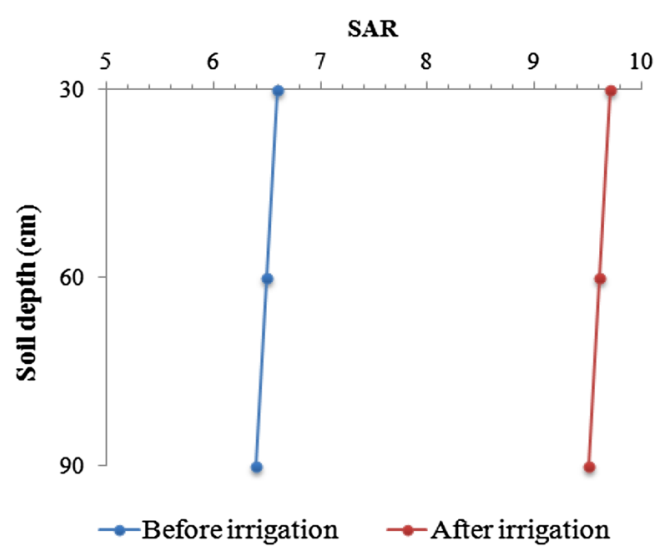

Fig. 4 Comparison of the sodium adsorption ratio (SAR) before and after irrigation

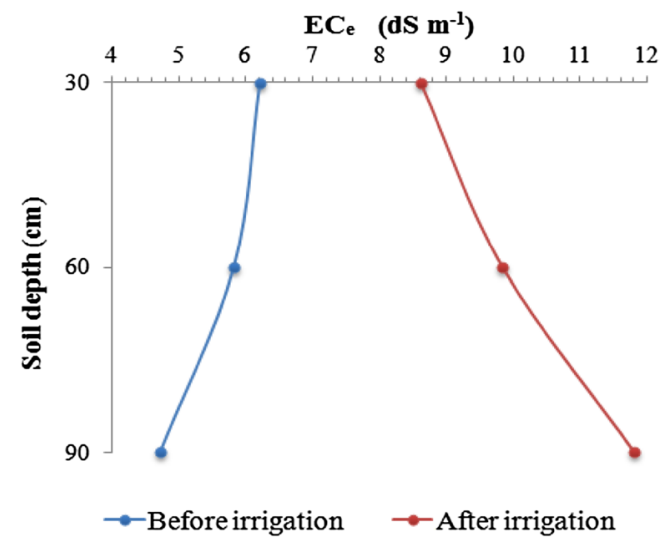

Fig. 5 Measured soil electrical conductivity $\left(\mathrm{EC}_{\mathrm{e}}\right)$ distributions before and after irrigation

$>1500 \mathrm{~mm} \mathrm{year}^{-1}$ ) and the extensive application of saline water (Sperling et al. 2014) are the main drivers of the major salinization observed in the irrigated areas of various Tunisian Saharan oases (Askri et al. 2014).

The changes in $\mathrm{EC}_{\mathrm{e}}$ with soil depth (Fig. 5) showed a slight increase in $\mathrm{EC}_{\mathrm{e}}$ in the topsoil layer $(0-30 \mathrm{~cm})$, whereas a substantial increase in $\mathrm{EC}_{\mathrm{e}}$ was noted for the bottom layer (60-90 cm, the high root density zone; Zaid and Jiménez 2002). Therefore, there is a high risk of decreasing crop production due to the impact of soil salinization on the root zone (Huang et al. 2011). The variations in $\mathrm{EC}_{\mathrm{e}}$ throughout the soil profile revealed that the leaching effect of the irrigation water (i.e., salt removal from soil) was significantly higher for the topsoil than for the deeper soil layers. This could be the main factor in the large difference between the $\mathrm{EC}_{\mathrm{e}}$ of the topsoil and that of the deep soil layer. As reported in many studies (e.g., El-Haddad and Noaman 2001; Mostafazadeh-Fard et al. 2007), accurate estimation of the leaching requirement is key to reducing soil desalinization. To calculate this, it is important to take into account the depth of the soil profile (to prevent soluble salt from being deposited in the deeper soil layers), the salinity threshold of the crop ( $4 \mathrm{dS} \mathrm{m}^{-1}$ for the date palm), and the salinity level of the applied water. As stated by Mostafazadeh-Fard et al. (2007), the accurate estimation of the leaching requirement, the application of irrigation water of a suitable salinity, and the use of a well-designed drainage system represent an effective overall approach to managing soil salinization in arid lands.

Regarding the physical properties of the studied soil, the hydraulic conductivity $\left(K_{\mathrm{s}}\right)$ of the irrigated soil decreased from 99.3 to $81.2 \mathrm{~cm} \mathrm{day}^{-1}$ and from 85.3 to $72.1 \mathrm{~cm} \mathrm{day}^{-1}$ in the $0-30 \mathrm{~cm}$ and $60-90 \mathrm{~cm}$ soil layers, respectively (Fig. 6). The major decrease in $K_{\mathrm{s}}$ over the studied period can be directly related to the observed increase in soil salinization. Increasing the water-soluble salt concentration in the soil can suppress soil dispersion, leading to a decrease in 


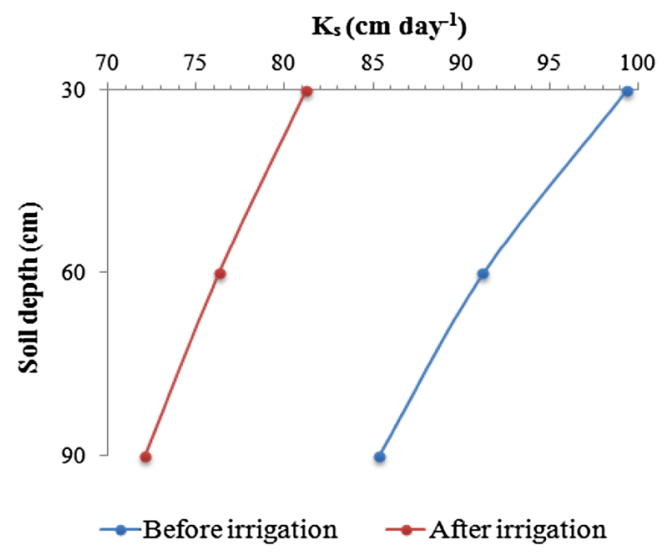

Fig. 6 Measured saturated soil hydraulic conductivity $\left(K_{\mathrm{s}}\right)$ values before and after irrigation at different soil depths

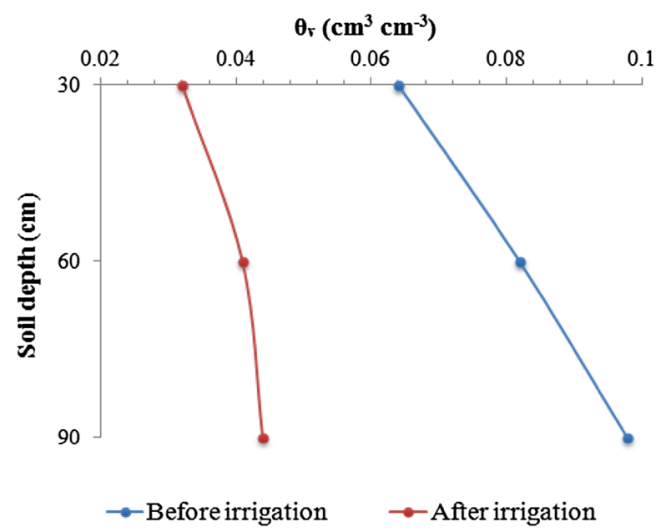

Fig. 7 Comparison between the volumetric water content $\left(\theta_{\mathrm{v}}\right)$ after the first irrigation event (January 2012) and that after the last irrigation event (December 2015)

hydraulic conductivity (Singh et al. 2011; Adhikari et al. 2014; Hanson et al. 1999). The observed decrease in $K_{\mathrm{s}}$ has a negative effect on the soil water content by decreasing the infiltration rate of the irrigation water into the soil profile. This argument is supported by measurements of the volumetric soil water content $\left(\theta_{\mathrm{v}}\right)$, as shown in Fig. 7.

$\theta_{\mathrm{v}}$ was measured after each irrigation event. The results revealed that for all soil layers, and assuming that the same amount of irrigation water was applied at each event, $\theta_{\mathrm{v}}$ generally decreased over the studied period. It appears that the decrease in $\theta_{\mathrm{v}}$ was primarily due to the long-term (four-year) application of saline groundwater to irrigate the palm trees in the studied oasis.

In summary, the results show that the evaluated physicochemical properties of the soil $\left(\mathrm{EC}_{\mathrm{e}}, \mathrm{pH}_{\mathrm{e}}, \mathrm{Ca}^{2+}, \mathrm{Mg}^{2+}\right.$, $\mathrm{Na}^{+}, \mathrm{SAR}, K_{\mathrm{s}}$, and $\theta_{\mathrm{v}}$ ) are interdependent; for example, an increase in $\mathrm{EC}_{\mathrm{e}}$ could cause a major increase in $K_{\mathrm{s}}$. Therefore, all of these soil properties should be taken into consideration when devising an appropriate soil and water management plan that has the potential to minimize the impact of saline water on irrigated soil.

\section{Effects of the irrigation treatments on the soil characteristics}

In this section, we present the effects of the different irrigation treatments applied to the three monitored plots (Table 2) on their soil properties. Duncan's multiple range (DMR) test at a significance level of 0.05 was utilized to compare the results of the three treatments. Based on the measurements obtained and the results of the statistical test, we were able to identify the irrigation treatment that minimized the negative effects of the saline water treatment on the soil physicochemical characteristics, thus optimizing plant growth and productivity. Table 5 summarizes the effects of the different irrigation treatments on the soil properties of each layer.

\section{Effect on soil electrical conductivity $\left(\mathrm{EC}_{\mathrm{e}}\right)$}

The results presented in Table 5 show a significant ( $p$ value $<0.05)$ difference in soil electrical conductivity $\left(\mathrm{EC}_{\mathrm{e}}\right)$ between the three irrigation treatments $\left(T_{1}, T_{2}\right.$, and $\left.T_{3}\right)$ for each soil layer. Figure 8 shows the average value of $\mathrm{EC}_{\mathrm{e}}$ recorded during the studied period for each irrigation treatment. According to the figure, it is evident that $\mathrm{EC}_{\mathrm{e}}$ built up to levels that exceeded the salt tolerance of date palms, estimated at $4 \mathrm{dS} \mathrm{m}^{-1}$ (Maas and Hoffman 1977). The main causes of this soil salinization are the high salinity of the irrigation water $\left(\mathrm{EC}_{\mathrm{iw}}=3.51 \mathrm{dS} \mathrm{m}^{-1}\right)$, the climatic conditions (especially the aridity and very low rainfall), and the soil properties (texture, salinity, etc.). However, a remarkable effect of the irrigation treatment on $\mathrm{EC}_{\mathrm{e}}$ was noted. For example, for the $0-30 \mathrm{~cm}$ soil layer, it was observed that the average $\mathrm{EC}_{\mathrm{e}}$ of the soil under treatment $T_{3}$ was $47.2 \%$ lower than the average $\mathrm{EC}_{\mathrm{e}}$ of the soil under treatment $T_{2}$. Comparison of the $\mathrm{EC}_{\mathrm{e}}$ values of the top layer under treatments $T_{3}$ and $T_{1}$ revealed that the $\mathrm{EC}_{\mathrm{e}}$ was $52.1 \%$ lower under treatment $T_{3}$. Thus, the high irrigation treatment substantially contributed to reducing soil salinity. As shown in Fig. 8, the observed decrease in $\mathrm{EC}_{\mathrm{e}}$ with the high treatment helped to reduce salinization stress by keeping the electrical conductivity of the soil close to the tolerance level (salinity threshold) of the date palm, which is about $4 \mathrm{dS} \mathrm{m}^{-1}$ (Maas and Hoffman 1977).

\section{Effect on soil water content $\left(\theta_{v}\right)$}

A significant difference ( $p$ value $<0.05$, Table 5 ) in soil water content $\left(\theta_{\mathrm{v}}\right)$ was observed between the different irrigation treatments. As shown in Fig. 9, a positive effect on $\theta_{\mathrm{v}}$ of increasing the amount of irrigation water applied was noted. As can be seen in the figure, for the $60-90 \mathrm{~cm}$ soil layer 
Table 5 Effects of the irrigation treatments [low $\left(T_{1}\right)$, medium $\left(T_{2}\right)$, and high $\left(T_{3}\right)$ treatments] on soil properties (mean \pm S.D. values are shown, as are significance levels)

\begin{tabular}{|c|c|c|c|c|c|c|c|}
\hline \multirow[t]{2}{*}{ Soil layer $(\mathrm{cm})$} & \multirow[t]{2}{*}{ Soil property } & \multicolumn{3}{|c|}{ Irrigation treatment } & \multicolumn{3}{|c|}{ Significance levels } \\
\hline & & $T_{1}$ & $T_{2}$ & $T_{3}$ & $\begin{array}{l}\text { Between } T_{1} \\
\text { and } T_{2}\end{array}$ & $\begin{array}{l}\text { Between } T_{1} \\
\text { and } T_{3}\end{array}$ & $\begin{array}{l}\text { Between } \\
T_{2} \text { and } \\
T_{3}\end{array}$ \\
\hline \multirow[t]{8}{*}{$0-30$} & $\mathrm{EC}_{\mathrm{e}}\left(\mathrm{dS} \mathrm{m} \mathrm{m}^{-1}\right)$ & $9.2 \pm 1.7$ & $7.41 \pm 1.1$ & $4.21 \pm 1.2$ & 0.039 & 0.031 & 0.035 \\
\hline & $\mathrm{pH}_{\mathrm{e}}(-)$ & $6.5 \pm 0.4$ & $6.85 \pm 0.6$ & $6.71 \pm 0.7$ & n.s. & n.s. & n.s. \\
\hline & $\mathrm{Na}^{+}\left(\right.$meq L $\left.{ }^{-1}\right)$ & $38.9 \pm 0.3$ & $39.5 \pm 3.2$ & $32.5 \pm 3.1$ & n.s. & 0.029 & 0.026 \\
\hline & $\mathrm{Ca}^{2+}\left(\right.$ meq L $\left.{ }^{-1}\right)$ & $27.2 \pm 1.3$ & $32.2 \pm 2.3$ & $29.2 \pm 2.6$ & n.s. & n.s. & n.s. \\
\hline & $\mathrm{Mg}^{2+}\left(\right.$ meq L $\left.{ }^{-1}\right)$ & $12.7 \pm 0.8$ & $15.6 \pm 1.3$ & $14.8 \pm 1.1$ & n.s. & n.s. & n.s. \\
\hline & SAR (-) & $10.4 \pm 1.5$ & $8.1 \pm 0.6$ & $6.6 \pm 0.8$ & 0.036 & 0.033 & 0.037 \\
\hline & $\mathrm{K}_{\mathrm{s}}\left(\mathrm{cm} \mathrm{day}^{-1}\right)$ & $92.2 \pm 0.6$ & $90.2 \pm 0.8$ & $91.2 \pm 0.5$ & n.s. & n.s. & n.s. \\
\hline & $\theta_{\mathrm{v}}\left(\mathrm{cm}^{3} \mathrm{~cm}^{-3}\right)$ & $0.034 \pm 0.003$ & $0.048 \pm 0.002$ & $0.055 \pm 0.001$ & 0.022 & 0.021 & 0.045 \\
\hline \multirow[t]{8}{*}{$30-60$} & $\mathrm{EC}_{\mathrm{e}}\left(\mathrm{dS} \mathrm{m} \mathrm{m}^{-1}\right)$ & $9.9 \pm 0.7$ & $7.8 \pm 0.9$ & $4.4 \pm 1.3$ & 0.041 & 0.033 & 0.037 \\
\hline & $\mathrm{pH}_{\mathrm{e}}(-)$ & $6.4 \pm 0.4$ & $6.7 \pm 0.5$ & $6.6 \pm 0.2$ & n.s. & n.s. & n.s. \\
\hline & $\mathrm{Na}^{+}\left(\right.$meq L $\left.\mathrm{L}^{-1}\right)$ & $37.1 \pm 0.3$ & $37.5 \pm 1.8$ & $31.1 \pm 0.5$ & n.s. & 0.031 & 0.028 \\
\hline & $\mathrm{Ca}^{2+}\left(\right.$ meq L $\left.{ }^{-1}\right)$ & $25.2 \pm 1.1$ & $30.4 \pm 1.9$ & $28.2 \pm 1.2$ & n.s. & n.s. & n.s. \\
\hline & $\mathrm{Mg}^{2+}\left(\right.$ meq L $\left.{ }^{-1}\right)$ & $11.5 \pm 0.8$ & $13.8 \pm 0.9$ & $13.6 \pm 0.3$ & n.s. & n.s. & n.s. \\
\hline & SAR (-) & $10.3 \pm 1.5$ & $8.1 \pm 06$ & $6.4 \pm 0.5$ & 0.038 & 0.035 & 0.039 \\
\hline & $\mathrm{K}_{\mathrm{s}}\left(\mathrm{cm} \mathrm{day}^{-1}\right)$ & $84.2 \pm 0.6$ & $83.7 \pm 0.9$ & $84.8 \pm 0.4$ & n.s. & n.s. & n.s. \\
\hline & $\theta_{\mathrm{v}}\left(\mathrm{cm}^{3} \mathrm{~cm}^{-3}\right)$ & $0.048 \pm 0.002$ & $0.061 \pm 0.003$ & $0.068 \pm 0.003$ & 0.024 & 0.023 & 0.047 \\
\hline \multirow[t]{8}{*}{$60-90$} & $\mathrm{EC}_{\mathrm{e}}\left(\mathrm{dS} \mathrm{m} \mathrm{m}^{-1}\right)$ & $12.4 \pm 1.7$ & $8.26 \pm 0.6$ & $4.7 \pm 0.3$ & 0.040 & 0.034 & 0.038 \\
\hline & $\mathrm{pH}_{\mathrm{e}}(-)$ & $6.1 \pm 0.4$ & $6.5 \pm 0.4$ & $6.3 \pm 0.2$ & n.s. & n.s. & n.s. \\
\hline & $\mathrm{Na}^{+}\left(\right.$meq L $\left.\mathrm{L}^{-1}\right)$ & $36.1 \pm 0.6$ & $35.4 \pm 2.4$ & $30.7 \pm 0.1$ & n.s. & 0.033 & 0.029 \\
\hline & $\mathrm{Ca}^{2+}\left(\right.$ meq L $\left.{ }^{-1}\right)$ & $23.2 \pm 1.2$ & $28.9 \pm 1.2$ & $25.2 \pm 1.5$ & n.s. & n.s. & n.s. \\
\hline & $\mathrm{Mg}^{2+}\left(\right.$ meq L $\left.{ }^{-1}\right)$ & $11.2 \pm 0.9$ & $12.8 \pm 1.3$ & $13.1 \pm 0.3$ & n.s. & n.s. & n.s. \\
\hline & SAR (-) & $10.1 \pm 1.5$ & $7.95 \pm 0.8$ & $6.1 \pm 0.5$ & 0.039 & 0.037 & 0.038 \\
\hline & $\mathrm{K}_{\mathrm{s}}\left(\mathrm{cm} \mathrm{day}^{-1}\right)$ & $79.25 \pm 0.6$ & $78.72 \pm 0.6$ & $79.81 \pm 0.4$ & n.s. & n.s. & n.s. \\
\hline & $\theta_{\mathrm{v}}\left(\mathrm{cm}^{3} \mathrm{~cm}^{-3}\right)$ & $0.055 \pm 0.002$ & $0.071 \pm 0.001$ & $0.075 \pm 0.003$ & 0.026 & 0.025 & 0.044 \\
\hline
\end{tabular}

n.s. not significant at the 0.05 level

Fig. 8 Average soil electrical conductivities $\left(\mathrm{EC}_{\mathrm{e}}\right)$ in the three soil layers under various irrigation treatments $\left(T_{1}, T_{2}\right.$, and $\left.T_{3}\right)$

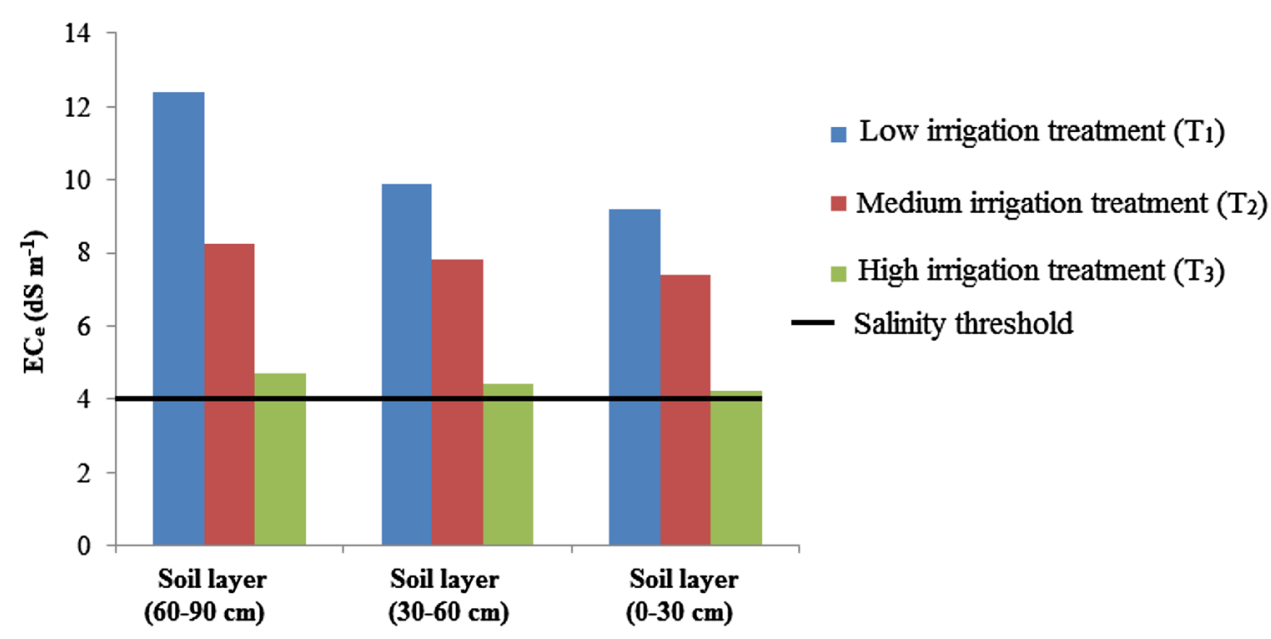

(the high root density zone), the average $\theta_{\mathrm{v}}$ was 24.7 and $14.1 \%$ higher under the treatment $T_{3}$ than under treatments $T_{1}$ and $T_{2}$, respectively (Fig. 9). These large decreases and increases in $\mathrm{EC}_{\mathrm{e}}$ and $\theta_{\mathrm{v}}$, respectively, were directly related to the application of $T_{3}$ during the studied period. As reported by many scholars (e.g., Haj-Amor et al. 2016; Askri et al. 
Fig. 9 Average soil water contents $\left(\theta_{\mathrm{v}}\right)$ of the three soil layers under various irrigation treatments $\left(T_{1}, T_{2}\right.$, and $\left.T_{3}\right)$

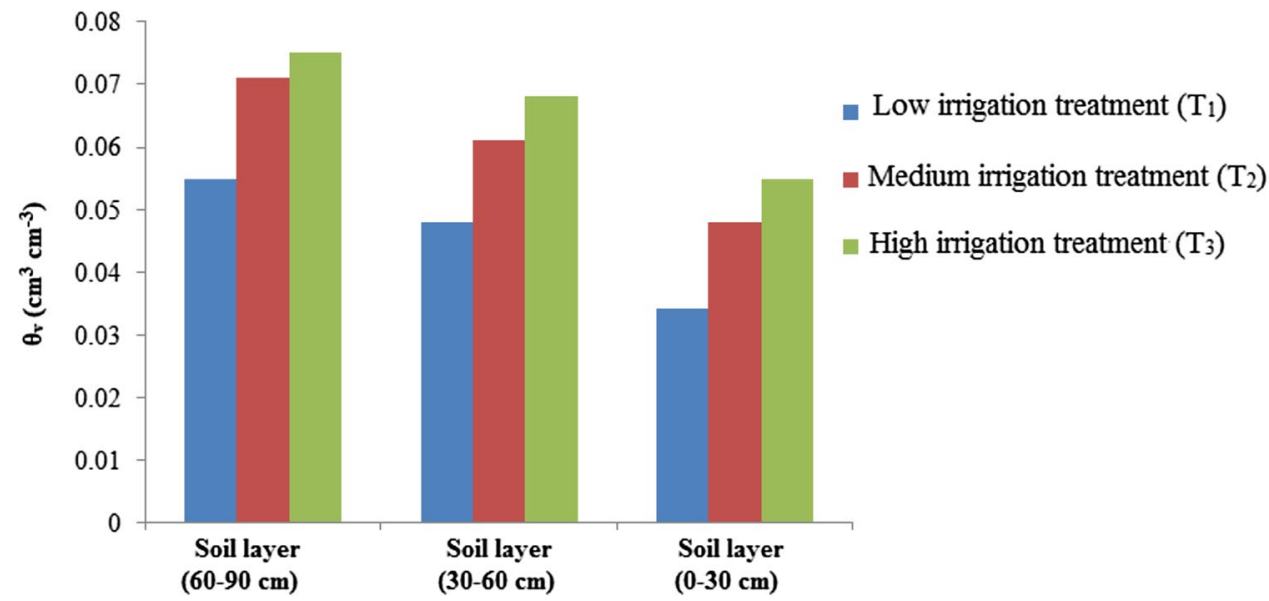

2014), improved knowledge of the $\mathrm{EC}_{\mathrm{e}}$ and $\theta_{\mathrm{v}}$ values of irrigated soil permits more accurate irrigation scheduling, thus reducing the negative effects of saline irrigation water on the agricultural soil.

\section{Effects on the $\mathrm{Ca}^{2+}, \mathrm{Mg}^{2+}$, and $\mathrm{Na}^{+}$concentrations and the SAR}

A comparison of the effects of the different irrigation treatments on the $\mathrm{Ca}^{2+}, \mathrm{Mg}^{2+}$, and $\mathrm{Na}^{+}$concentrations is provided in Table 5 . As can be seen in the table, for all three investigated soil layers, the concentrations of $\mathrm{Ca}^{2+}$ and $\mathrm{Mg}^{2+}$ did not vary significantly with the irrigation treatment applied. However, the $\mathrm{Na}^{+}$concentration was significantly ( $p$ $<0.05$ ) lower for treatment $T_{3}$ (relative to the $\mathrm{Na}^{+}$concentrations for $T_{1}$ and $T_{2}$ ). The decrease in $\mathrm{Na}^{+}$concentration under the high irrigation treatment could help to enhance date palm growth. As depicted in Fig. 10, for all soil layers, the lowest average value of the sodium adsorption ratio (SAR) was obtained with the high irrigation treatment. This is directly related to the significant decrease in $\mathrm{Na}^{+}$concentration under $T_{3}$ (Fig. 10).

\section{Effect on $\mathrm{pH}_{\mathrm{e}}$}

The results presented in Table 5 suggest that $\mathrm{pH}_{\mathrm{e}}$ and $K_{\mathrm{s}}$ were not significantly influenced by the treatment applied during the studied period. The $\mathrm{pH}_{\mathrm{e}}$ measured in each plot was in good agreement with the results of the study conducted by Rahil et al. (2013), who showed that the $\mathrm{pH}$ of the irrigated soil was not affected by the amount of saline irrigation water applied. This study revealed that the $\mathrm{pH}$ is a function of the quality (especially the salinity level) of the irrigation water, not the quantity of irrigation water used.

\section{Effect on $K_{\mathrm{s}}$}

The hydraulic conductivity $\left(K_{\mathrm{s}}\right)$ of the soil also did not differ significantly between the three monitored plots (i.e., did not vary with the irrigation treatment applied; see Table 5). This can be explained by the fact that $K_{\mathrm{s}}$ is mainly dependent on the quality of the irrigation water (Bardhan et al. 2007).

As discussed above, it is evident that when the date palms were irrigated frequently (every 15 days over the 4-year period) with saline water $\left(2.24 \mathrm{~g} \mathrm{l}^{-1}\right)$, the high irrigation
Fig. 10 Average sodium adsorption ratios (SAR) for the three soil layers of interest under various irrigation treatments $\left(T_{1}, T_{2}\right.$, and $T_{3}$ )

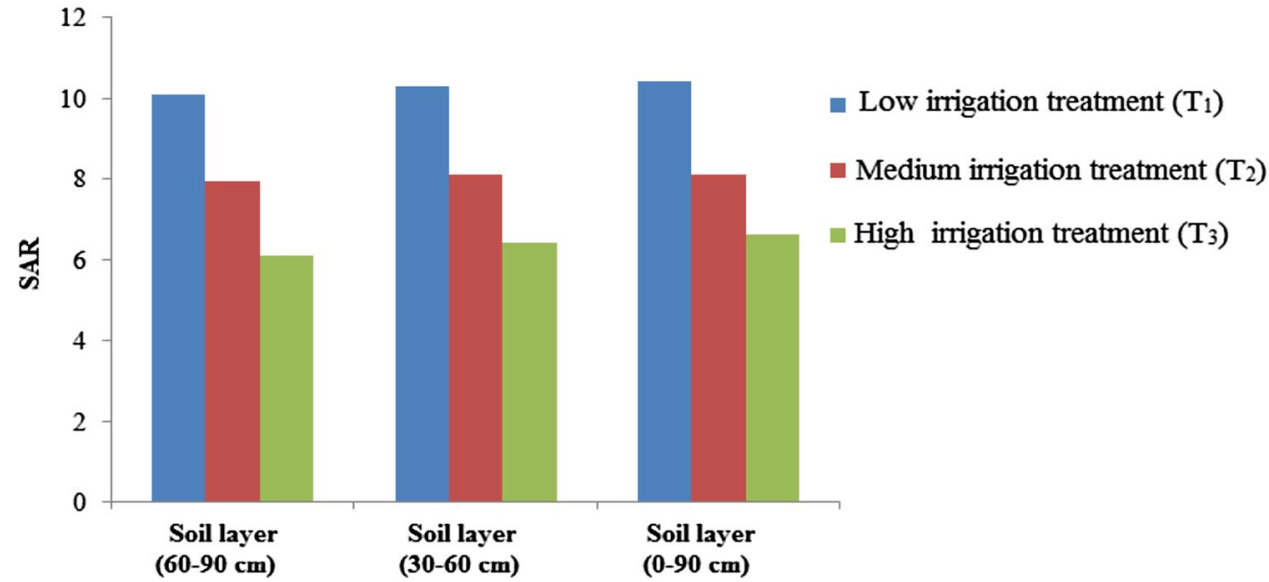


treatment (i.e., applying $110 \%$ of the net irrigation requirement of date palms) was the best irrigation strategy for maintaining the appropriate properties of the irrigated soil and thus achieving the highest potential yield of planted trees. Such an approach requires continuous control of the irrigation water and soil properties (Bouksila et al. 2013), and considerable effort must be made to educate farmers about the tremendous benefits of the high irrigation treatment for soil productivity. Therefore, as stated by Ghazouani et al. (2009), special attention should be paid to improving farmers' awareness of the effects of irrigation strategy, particularly the combined influence of water quantity and quality, on soil characteristics. Our understanding of the water management strategy currently employed in the studied oasis and the findings of Ghazouani et al. (2009) both suggest that the farmers' perceptions of water conservation and their application of a low irrigation treatment have degraded the studied region's soil productivity. Therefore, the farmers should be educated about the need to ensure sustainable agricultural activity in the studied oasis by applying the appropriate long-term strategy for irrigating with saline water. On the other hand, a similar study has shown that the farmers have the ability to adapt and reduce the problems caused by soil salinization due to their long-term practical experience (Omrani and Dieter 2012).

\section{Conclusion}

We monitored the characteristics of the soil in three plots in the Dergine Oasis that were irrigated with different quantities of saline water $\left(3.5 \mathrm{dS} \mathrm{m}^{-1}\right)$ over a period of four years (2012-2015), and observed that irrigation of the plots with the saline water had severe effects on the chemical and physical properties of the soil. The soil properties investigated included its electrical conductivity $\left(\mathrm{EC}_{\mathrm{e}}\right)$, the $\mathrm{pH}$ of the saturated soil paste $\left(\mathrm{pH}_{\mathrm{e}}\right)$, the concentrations of various soluble cations $\left(\mathrm{Ca}^{2+}, \mathrm{Mg}^{2+}, \mathrm{Na}^{+}\right)$, the sodium adsorption ratio (SAR), the soil hydraulic conductivity $\left(K_{\mathrm{s}}\right)$, and the volumetric water content of the soil $\left(\theta_{\mathrm{v}}\right)$. Soil property values measured before the start of each irrigation treatment (in January 2012) were compared with those measured at the end of the studied period (December 2015). Analysis of the resulting data revealed that there was a high risk of soil quality deterioration in terms of $\mathrm{EC}_{\mathrm{e}}, \mathrm{SAR}$, and $K_{\mathrm{s}}$ in the near future unless an appropriate irrigation water and soil management strategy is established in the studied Saharan oasis. Among the three irrigation treatments applied to the plots, i.e., a low treatment ( $90 \%$ of NIR), a medium treatment $(100 \%$ of NIR), and a high treatment ( $110 \%$ of NIR), the high treatment strategy yielded the best results, as it suppressed the soil salinization process through leaching. The findings of this study could be applied to other typical
Saharan oases that are irrigated with saline water in order to optimally manage the salinization process and potentially prevent further soil deterioration in Saharan croplands.

Acknowledgements The present work was financially supported by the Ministry of Agriculture, Tunisia. The authors thank the Agriculture Development Office of Kebili, Tunisia for technical support. The second author acknowledges the support of the Swedish Research Council for Environment, Agricultural Sciences, and Spatial Planning (FORMAS, grant: 220-2014-977). The authors would also like to thank Hafedh Rigane (Faculty of Sciences of Sfax, Tunisia) for his thoughtful recommendations.

\section{Compliance with ethical standards}

Conflict of interest The present paper is an original work and the authors all declare that they have no conflict of interest.

Open Access This article is distributed under the terms of the Creative Commons Attribution 4.0 International License (http://creativecommons.org/licenses/by/4.0/), which permits unrestricted use, distribution, and reproduction in any medium, provided you give appropriate credit to the original author(s) and the source, provide a link to the Creative Commons license, and indicate if changes were made.

\section{References}

Adhikari P, Shukla MK, Mexal JG, Daniel D (2014) Irrigation with treated wastewater: quantification of changes in soil physical and chemical properties. Irrig Drain Syst Eng 3:2

Al-Rasbi SAR (2010) Evaluation of the growth of date palm seedlings irrigated with saline water in Sultanate of Oman. Ph.D. thesis. Department of Landscape Ecology and Nature Conservation, University of Kassel, Germany

Al-Zu'bi Y (2007) Effect of irrigation water on agricultural soil in Jordan valley: an example from arid area conditions. J Arid Environ 7:63-79

Amézketa E (1999) Soil aggregate stability: a review. J Sustain Agric 14:83-151

Askri B, Bouhlila R (2010) Evolution de la salinité des oasis modernes de la Tunisie. Revue Étude et Gestion des Sols 17:197-212

Askri B, Bouhlila R, Job JO (2010) Development and application of a conceptual hydrologic model to predict soil salinity within modern Tunisian oases. J Hydrol 380:45-61

Askri B, Ahmed AK, Abichou T, Bouhlila R (2014) Effects of shallow water table, salinity and frequency of irrigation water on the date palm water use. J Hydrol 513:81-90

Bardhan G, Chaudhari SK, Mohapatra PK (2007) Effect of irrigation water quality on saturated hydraulic conductivity of typic haplustert, vertic haplustept, and lithic ustorthent soils. J Agric Phys $7: 38-46$

Ben Aissa I, Bouarfa S, Vincent B, Chaumont C, Perrier A (2013) Drainage performance assessment in a modernized oasis system. Irrig Drain 62:221-228

Blake GR, Hartge KH (1986) Bulk density. In: Klute A (ed) Methods of soil analysis, part 1-physical and mineralogical methods, 2nd edn. Soil Science Society of America, Madison, pp 363-376

Bouarfa S, Marlet S, Douaoui A, Hartani T, Mekki I, Ghazouani W, Ben Aïssa I, Vincent B, Hassani F, Kuper M (2009) Salinity patterns in irrigation systems, a threat to be demystified, a constraint 
to be managed: field evidence from Algeria and Tunisia. Irrig Drain 58(SI3):S273-S284

Bouksila F, Bahrib A, Berndtssonc R, Persson M, Rozema J, Van der Zee SEATM (2013) Assessment of soil salinization risks under irrigation with brackish water in semiarid Tunisia. Environ Exp Bot 92:176-185

Cichota R, Hurtado ALB, van Lier Q (2008) Performance of a multilevel TDR system exposed to tropical field conditions-a timespace comparison with tensiometry. J Hydrol 352:181-190

De Grenade R (2013) Date palm as a keystone species in Baja California peninsula, Mexico oases. J Arid Environ 94:59-69

Duncan DB (1955) Multiple range and multiple F tests. Biometrics $11: 1-42$

El-Fahem T (2003) Salinization of groundwater in the Nefzaoua Oases: South Tunisia. Thesis. Swiss Federal Institute of Technology, Zürich

El-Haddad E-SH, Noaman MM (2001) Leaching requirement and salinity threshold for yield and agronomic characteristics of halophytes under salt stress. J Arid Environ 49:865-874

FAO (1989) Arid zone forestry: a guide for field technicians. FAO Conservation Guide 20. FAO, Rome

Gee GW, Bauder JW (1986) Particles size analysis. In: Klute A (ed) Methods of soil analysis. Part 1. Physical and mineralogical methods, vol 9, 2nd edn. American society of agronomy/Soil science society of America, Madison, pp 383-411

Ghazouani W, Marlet S, Mekki I, Vidal A (2009) Farmers' perceptions and engineering approach in the modernization of a communitymanaged irrigation scheme, a case study from an oasis of the Nefzawa (South of Tunisia). Irrig Drain 58:S285-S296

Gholizadeh-Sarabi S, Sepaskhah AR (2013) Effect of zeolite and saline water application on saturated hydraulic conductivity and infiltration in different soil textures. Arch Agron Soil Sci 59(5):753-764

Haj-Amor Z, Ibrahimi MK, Feki N, Lhomme JP, Bouri S (2016) Soil salinization and irrigation management of date palms in a Saharan environment. Environ Monit Assess 188(8):1-17

Hamdy A (2005) Saline irrigation management for a sustainable use. In: Hamdy A, El Gamal F, Lamaddalena N, Bogliotti C, Guelloubi R (eds) Non-conventional water use: WASAMED project. CIHEAM/EU DG Research, Bari, pp 3-42

Hamouda W, Hachicha M, Mellouli HJ, Zidi CH (2005) Effet de la salinité sur la détermination de l'humidité du sol par la méthode de la réflectométrie dans le domaine temporel (TDR) et par les capteurs de tension d'eau (Effect of salinity on the determination of soil moisture by time domain reflectometry (TDR) and watermark sensors). 30émes journées GFHN, Tunis, $p 7$

Hanson B, Grattan SR, Fulton A (1999) Agricultural salinity and drainage. University of California Irrigation Program, University of California, Davis

Huang CH, Xue X, Wang T, De Mascellis R, Mele G, You QG, Peng F, Tedeschi A (2011) Effects of saline water irrigation on soil properties in northwest China. Environ Earth Sci 63:701-708

King C, Thomas David SG (2014) Monitoring environmental change and degradation in the irrigated oases of the Northern Sahara. J Arid Environ 103:36-45

Kinnear PR, Gray CD (2000) SPSS for Windows made simple: release 10. Taylor \& Francis, Abingdon

Knapp K, Baerenklau K (2006) Groundwater quantity and quality management: agricultural production and aquifer salinization over long time scales. J Agric Resour Econ 31:616-641
Kolsi SH, Bouri S, Hachicha W, Dhia HB (2013) Implementation and evaluation of multivariate analysis for groundwater hydrochemistry assessment in arid environments: a case study of Hajeb Elyoun-Jelma, Central Tunisia. Environ Earth Sci 70:2215-2224

Maas EV, Hoffman GJ (1977) Crop salt tolerance-current assessment. ASCE J Irrig Drain Div 103:115-134

Mostafazadeh-Fard B, Heidarpour M, Aghakhani A, Feizi M (2007) Effects of irrigation water salinity and leaching on soil chemical properties in an arid region. Int J Agric Biol 3:466-469

Omrani N, Dieter B (2012) Water management issue in Southern Tunisia under a climate change context. In: Leal Filho W (ed) Climate change and the sustainable use of water resources. Springer, Berlin, pp 225-235

Oster JD, Sposito G (1980) The Gapon coefficient and the exchangeable sodium percentage-sodium adsorption ratio relation. Soil Sci Soc Am J 44:258-260

Page AL, Miller RH, Keeney DR (1982) Methods of soil analysis, chemical and microbiological properties. American Society of Agronomy, Madison

Rahil M, Hajjeh H, Qanadillo A (2013) Effect of saline water application through different irrigation intervals on tomato yield and soil properties. Open J Soil Sci 3(3):143-147

Rhoades JD (1996) Salinity: electrical conductivity and total dissolved solids. In: Spark DL (ed) Methods of soil analysis, part 3: chemical methods. SSSA Book Series no. 5. ASA/SSSA, Madison

Roy RN, Finck A, Blair GJ, Tandon HLS (2006) Plant nutrition for food security, a guide for integrated nutrient management. FAO Fertilizer and Plant Nutrition Bulletin 16. FAO, Rome

Shrivastava P, Kumar R (2015) Soil salinity: a serious environmental issue and plant growth promoting bacteria as one of the tools for its alleviation. Saudi J Biol Sci 22(2):123-131

Singh AP, Singh A, Tiwari HL, Dwivedi PK (2011) The effect of salts of the hydraulic conductivity of the saline alkali soil. Indian J Sci Res 4:117-119

Sperling O, Shapira O, Tripler E, Schwartz A, Lazarovitch N (2014) A model for computing date palm water requirements as affected by salinity. Irrig Sci 32:341-350

Tedeschi A, Dell'Aquila R (2005) Effects of irrigation with saline waters, at different concentrations, on soil physical and chemical characteristics. Agric Water Manag 77:308-322

Tedeschi A, Menenti M, Tedeschi P Wang T, Xue X, Basile A, Mele G, De Lorenzi F, De Mascellis R, Di Matteo B (2007) Design and evaluation of saline irrigation schedules to cope with droughts and scarce fresh water. In: Proc ICID 22nd European Regional Conf on Water Resources Management and Irrigation and Drainage Systems Development in the European Environment, Pavia, Italy, 2-6 Sept 2007

Tripler E, Shani U, Mualem Y, Ben-Gal A (2011) Long-term growth, water consumption and yield of date palm as a function of salinity. Agric Water Manag 99:128-134

Zaid A, Jiménez EJ (2002) Chapter I: botanical and systematic description of the date palm. In: Date palm cultivation. FAO Plant Production and Protection Paper 156, Rev. 1. FAO, Rome

Zaidi FK, Kassem OMK (2012) Use of electrical resistivity tomography in delineating zones of groundwater potential in arid regions: a case study from Diriyah region of Saudi Arabia. Arab J Geosci $5(2): 327-333$ 